\title{
Septo-optic dysplasia
}

\author{
Karina de Ferran', Isla Aguiar Paiva', Daniel Luiz Schueftan Gilban², \\ Monique Resende 3 , Micheline Abreu Rayol de Souza33, \\ Izabel Calland Ricarte Beserra4 ${ }^{4}$ Marilia Martins Guimarães ${ }^{4}$
}

\begin{abstract}
Septo-optic dysplasia (SOD), also referred to as de Morsier syndrome, is a rare congenital condition, characterized by two of the classic triad features: midline brain abnormalities, optic nerve hypoplasia $(\mathrm{ONH})$ and pituitary endocrine dysfunction. We report 5 children with SOD, originally referred to be evaluated due to short stature, who also presented bilateral optic nerve hypoplasia, nystagmus and development delay. In 4 of the patients, we identified neuroimaging abnormalities of the hypothalamo-pituitary axis such as anterior pituitary hypoplasia (3/5), ectopic posterior pituitary (4/5), thin or absent stalk (3/5) and empty sella (1/5). We also encountered diverse pituitary deficiencies: growth hormone $(3 / 5)$, adrenocorticotropic hormone (3/5), thyroid-stimulating hormone (2/5) and antidiuretic hormone (1/5). Only one child presented intact pituitary function and anatomy. Although rare, SOD is an important cause of congenital hypopituitarism and it should be considered in children with optic nerve hypoplasia or midline brain abnormalities for early diagnosis and treatment.
\end{abstract}

Key words: septo-optic dysplasia, optic nerve/abnormalities, hypopituitarism.

\section{Displasia septo-óptica}

\section{RESUMO}

A displasia septo-óptica (DSO, síndrome de Morsier) é uma condição congênita rara definida por dois critérios da tríade: defeitos de linha média, hipoplasia de nervo óptico e insuficiência hipotálamo-hipofisária. Descrevemos 5 casos de DSO, encaminhados por baixa estatura, com hipoplasia dos nervos ópticos, nistagmo e atraso global do desenvolvimento. Destes, 4 possuem alteração na ressonância magnética de sela túrcica e insuficiência hipotálamo-hipofisária, tendo sido observada adeno-hipófise hipoplásica (3/5), neuro-hipófise ectópica (4/5), haste afilada/ausente (3/5) e sela vazia (1/5), além de déficit dos eixos somatotrófico (3/5), adrenocorticotrófico (3/5), tireotrófico (2/5) e do hormônio antidiurético (1/5). Apenas um paciente não apresenta alteração anatômica ou funcional do eixo hipotálamo-hipofisário. Embora rara, a DSO é causa importante de hipopituitarismo congênito, devendo ser considerada em crianças com hipoplasia de nervo óptico ou defeito de linha média para seu diagnóstico e tratamento precoces, evitando seqüelas graves.

Palavras-chave: displasia septo-óptica, nervo óptico/anormalidades., hipopituitarismo.

Septo-optic dysplasia (SOD) is a rare congenital condition, initially described by Reeves in $1941^{1}$. Also known as de Morsier syndrome ${ }^{2}$, its relative incidence is $1 / 10,000$ live births ${ }^{3}$. The SOD phenotype is highly heterogeneous, being defined by the association of two out of three fea- tures: optic nerve hypoplasia $(\mathrm{ONH})$, midline abnormalities and hypothalamic-pituitary endocrine deficiencies ${ }^{1-8}$. Only $30 \%$ of the cases will present the complete triad ${ }^{9}$. Due to the high prevalence of neuroradiological abnormalities and pituitary dysfunction within the group of patients with 
$\mathrm{ONH}(60 \%)$, the individuals with any component of the syndrome must be completely screened for any of the other features ${ }^{9}$.

\section{Etiology of the SOD}

Most SOD cases are sporadic and several etiologies have been postulated, like viral infections, gestational diabetes, environmental teratogens, vascular or degenerative injury and genetic mutations s,12,14-16. $^{10}$.

The association of low maternal age with SOD is not consensus $^{3,15,16}$. A revision study of 100 patients with ONH identified association with prematurity in $21 \%$, fetal alcohol syndrome in $9 \%$, maternal diabetes in $6 \%$ and endocrine abnormalities in $6 \%{ }^{17}$.

Studies in mice showed that the disruption of the homeobox gene Hesx 1 produces a phenotype similar to $\mathrm{SOD}^{4}$. A familiar case study was pioneer and identified a missense mutation in the gene HESX1 in a highly consanguineous family with SOD, allowing the confirmation of the hypothesis ${ }^{4}$. Until now, 13 different new mutations have already been described in the gene HESX1, responsible for different phenotypes of the syndrome ${ }^{7}$. These mutations are quite rare $(<1 \%)$, suggesting that other genes, probably interacting with the environment, contribute to the syndrome ${ }^{7}$.

\section{Optic nerve hypoplasia}

$\mathrm{ONH}$ is generally the first manifestation of the syndrome $^{18}$. It is usually segmental or partial in $71 \%$, being diffused or complete on the remaining $\operatorname{cases}^{10}$. It can be uni or bilateral, being the second more common $(>70 \%)^{6,17,19}$.

Most of the patients have low visual acuity and nystagmus ${ }^{6,11,17,19}, 80 \%$ being considered legally blind ${ }^{11}$. Astigmatism is also common ${ }^{6}$.

\section{Midline abnormalities in the central nervous system}

Midline abnormalities include a great phenotype spectrum ${ }^{4}$, being agenesis of corpus callosum, absence of the septum pellucidum, cerebellar hypoplasia, aplasia of the fornix and schizencephaly the most common findings in the syndrome ${ }^{6,8}$. The magnetic resonance imaging (MRI) findings are heterogeneous including morphological anomalies of the cortex and malrotation of the hippocampus ${ }^{19}$. About half of the patients have absence of the septum pellucidum and/or of the corpus callosum ${ }^{11}$.

Neuroradiological anomalies are present in up to 75$80 \%$ of the patients with $\mathrm{ONH}$, rising to $90 \%$ in those with associated neurological deficits ${ }^{8,20}$.

Ectopic posterior pituitary predicts the existence of pituitary hormone deficiency, while hemispheric migration anomalies are predictors of neurodevelopmental def- icits $^{8}$. Intracranial arachnoid and epidermoid cysts also seem to be associated ${ }^{6}$ with, as arachnoid cysts are present in $12.5 \%$ of the patients, possibly being the cause of the injury to the optic tract or derived from a common etiopathogenic process ${ }^{21-23}$.

Mild to moderate neurological disorders are observed in most patients with SOD (70\%). The electroencephalogram (ECG) is normal in half of the cases ${ }^{19,21}$. The anomalies vary from developmental delay to focal deficits, like epilepsy and hemiparesis ${ }^{7,15,20}$. About $60 \%$ of the patients with bilateral ONH have some kind of neurological disorder, but the prevalence of developmental delay, mental retardation, cerebral palsy and seizures is not a consensus according to different studies ${ }^{17,22}$. Hydrocephalus or a seizure disorder are more frequently seen in patients with developmental delay ${ }^{24,25}$.

Seizures and developmental delay can occur due to metabolic and/or neuroanatomical disorders present in patients with SOD, especially in cases with associated hypoglycemia or hypernatremia ${ }^{24}$.

\section{Pituitary hormone deficiency}

Pituitary hypoplasia manifests itself in different degrees of hormone deficiency, from a single hormone deficit to panhypopituitarism ${ }^{4,5,7,11,19,24,25}$. The deficiencies also can evolve gradually over time $e^{7,18,25}$.

Growth hormone (GH) deficiency is the most common, followed by adrenocorticotropic hormone (ACTH) and tireotrophic hormone (TSH) deficiencies ${ }^{21,24}$. Gonadotrophic function is generally preserved ${ }^{26}$ and diabetes insipidus is found more rarely ${ }^{5,26}$.

Hypopituitarism, even with signs initiated in the neonatal period, usually is diagnosed much later, which brings great risk of death and brain injury ${ }^{27}$. The hypoglycemia, presence of micropenis and/or cryptorchidism with hypoplastic testes, prolonged jaundice or manifestation of $d i$ abetes insipidus are clinical signs that may alert to the existence of hypopituitarism, allowing an earlier diagnosis ${ }^{27}$.

Diabetes insipidus can evolve with hypocortisolism and thermoregulation disturbance, resulting in unexpected deaths ${ }^{28}$.

Hypothalamic disfunction or malformation is also described in the syndrome and the hypopituitarism seems to be secondary to hypothalamic injury rather than to intrinsic pituitary defect ${ }^{13}$.

\section{METHOD}

We describe the clinical and radiological findings of five patients with the diagnosis of septo-optic dysplasia, sent to an outpatient clinic of pediatric endocrinology due to short stature.

All patients were evaluated by a pediatric ophthalmologist, through direct ophthalmoscopy. All children had a 
magnetic resonance imaging of the brain and hypothalamic-pituitary axis. The images were evaluated by the same method by one investigator.

Height, weight and the pubertal status were monitored. Data concerning previous and presenting symptoms, perinatal history, development and clinical examination were collected from the medical records.

Endocrine function was assessed by a pediatric endocrinologist periodically and all of the biological evaluations were performed in the same laboratory.

All patients gave an informed consent for this publication.

\section{RESULTS}

The clinical and radiological features are shown on the Tables 1 and 2, respectively.
All cases were born full term and two were born small for the gestational age (SGA), both male. None of the patients had complications during the prenatal period and only one had fetal distress, solved by the interruption of the pregnancy by cesarean surgery. None of the mothers reported alcoholism, smoking, drug abuse or any selfmedication during the pregnancy or the postnatal period.

All 5 patients were early diagnosed with bilateral $\mathrm{ONH}$, with severe visual loss and bilateral nystagmus. Ocular disturbances were the first symptoms observed by the mothers in 3 out of 5 cases (cases 1, 2, and 3) and the $\mathrm{ONH}$ had been diagnosed before the first year in 4 out of 5 patients.

As first symptom of SOD, the two remaining patients (cases 4 and 5) had a severe episode of neonatal hypoglycemia in the first 24 hours of life, evolving with seizures

Table 1. Clinical features and hormone deficiencies.

\begin{tabular}{|c|c|c|c|c|c|}
\hline & Case 1 & Case 2 & Case 3 & Case 4 & Case 5 \\
\hline Gender & M & M & $\mathrm{F}$ & $\mathrm{F}$ & $\mathrm{F}$ \\
\hline $\begin{array}{l}\text { Age at diagnosis of ONH } \\
\text { by ophthalmoscopy* }\end{array}$ & 0.5 & 0.4 & 1.0 & 3.0 & 0.3 \\
\hline Age at diagnosis of SOD* & 7.3 & 2.4 & 6.4 & 7.5 & 13 \\
\hline $\begin{array}{l}\text { Age of referral to the pediatric } \\
\text { endocrinology outpatient clinic* }\end{array}$ & 3.7 & 7.6 & 5.6 & 4.6 & 13 \\
\hline Clinical findings & $\begin{array}{l}\text { Nystagmus, } \\
\text { ONH, DD }\end{array}$ & $\begin{array}{l}\text { Nystagmus, } \\
\text { ONH, DD }\end{array}$ & $\begin{array}{l}\text { Nystagmus, } \\
\text { ONH, DD }\end{array}$ & $\begin{array}{l}\text { Nystagmus, ONH, } \\
\text { DD, hypoglycemia } \\
\text { follow by seizures }\end{array}$ & $\begin{array}{l}\text { Nystagmus, ONH, DD, } \\
\text { hypoglycemia follow by } \\
\text { seizures and cardiac arrest, } \\
\text { constipation and paucity } \\
\text { of pubic and axillaries hair }\end{array}$ \\
\hline Z escore (height) & -5.7 & -3.0 & -5.9 & -4.8 & -3.9 \\
\hline First deficiency (age of diagnosis) & $\mathrm{ADH}(7.8)$ & $\begin{array}{c}\text { Absent } \\
\text { (untill 11.2) }\end{array}$ & $\mathrm{GH}(6.6)$ & TSH (4.7) & Indetermined (13) \\
\hline Deficient hormone nowadays & $\mathrm{ADH}$ & - & $\mathrm{GH}$ and $\mathrm{ACTH}$ & $\mathrm{TSH}, \mathrm{ACTH}$ and $\mathrm{GH}$ & $\mathrm{TSH}, \mathrm{ACTH}$ and probably $\mathrm{GH}$ \\
\hline
\end{tabular}

*Age in years; ONH: optic nerve hypoplasia; DD: developmental delay; $\mathrm{ADH}$ : anti-diuretic hormone; M: male; F: female.

Table 2. Neuroimaging of brain and hypothalamic-pituitary axis by MRI.

\begin{tabular}{cll}
\hline Case & Brain MRI & Hypothalamic-pituitary axis MRI \\
\hline 1 & $\begin{array}{l}\text { Schizencephaly, absent septum pellucidum, cortical } \\
\text { dysplasia, left hypoplasia of temporal lobe, right } \\
\text { temporal arachnoid cyst. }\end{array}$ & $\begin{array}{l}\text { Hypoplastic anterior pituitary, ectopic posterior pituitary, stalk not } \\
\text { identified. }\end{array}$ \\
2 & $\begin{array}{l}\text { Schizencephaly, left parietal arachnoid cyst, gliosis } \\
\text { on white matter. }\end{array}$ & Normal. \\
3 & $\begin{array}{l}\text { Absent septum pellucidum, hypoplasia of chiasm } \\
\text { and optic nerve. }\end{array}$ & Hypoplastic anterior pituitary, absent posterior pituitary, thin stalk. \\
4 & $\begin{array}{l}\text { Diffuse thinning of chiasm and optic nerve, right } \\
\text { arachnoid cyst. }\end{array}$ & Empty sella, ectopic posterior pituitary, stalk not identified. \\
5 & Diffuse thinning of chiasm. & Hypoplastic anterior pituitary, ectopic posterior pituitary, thin stalk. \\
\hline
\end{tabular}


and the need of intensive care. One of the patients presented cardiorespiratory arrest secondary to the hypoglycemia (case 5).

Four out of five cases presented developmental delay.

In average, the diagnosis of SOD was made by the age of 7.3, varying from 2.4 to 13 years of age. One patient was diagnosed by the genetics service (case 1) and the others by the endocrinology clinic.

All the patients were forwarded to the endocrinology clinic due to short stature at ages ranging from 3.7 to 13 , with an average of 6.9 years of age. The average of $Z$ score for stature at the time of admission in the endocrinology department was of -4.7 standard deviation (SD), varying from -3.0 to $-5.9 \mathrm{SD}$ for age and gender. Two patients presented hypoglycemia during the infancy associated with short stature and one of them also presented constipation and paucity of pubic and axillaries hair (case 5) at admission. After hormonal assessment, GH deficiency was diagnosed in 2 cases, one being an isolated deficiency (case 3) and the other a case of panhypopituitarism with associated cortisol and thyroid hormone deficiencies (case 4). The case with isolated GH deficiency evolved with cortisol insufficiency after 1 year of monitoring. Case 5 presented cortisol and thyroid hormone deficiencies and is under investigation for deficit of GH. Case 1 has isolated diabetes insipidus and case 2 has not presented any deficiency until now (11.2 years). The patients with hypoglycemia were succefully treated with glucocorticoid replacement.

All patients with hormonal deficiency have abnormalities in the hypothalamic-pituitary axis on neuroimaging. Case 4 has an empty sella and the other three (cases 1, 3 and 5) present hypoplastic anterior pituitary. Cases 1, 4 and 5 have an ectopic posterior pituitary and the neurohypophysis was not seen in case 3 . A thin stalk was spotted in cases 3 and 5, but could not be identified in case 1 and 4. Only one case had no hypothalamic-pituitary axis anomaly (case 2).

On the brain MRI, all patients presented midline malformations. Two presented schizencephaly (cases 1 and 2 ) and two had absent septum pellucidum (cases 1 and 3). In three cases (3, 4 and 5), the MRI detected the anomaly on the optic tract, with diffused hypoplasia of the chiasm and optic nerve. Three patients also presented arachnoid cysts (case 1, 2 and 4).

\section{DISCUSSION}

Our cohort is of 5 patients referred to the Pediatric Endocrinology Department, being two from Neurology and one from Ophthalmology. The two others were referred by the General Pediatric Clinic. We observed that 4 of the 5 cases have endocrine disfunction and this is probably a selection bias, since the patients were referred to our outpatient clinic due to short stature of possible endocrine causes.

All patients had bilateral $\mathrm{ONH}$ early diagnosed by a specialist, but only one was forwarded by the ophthalmologist to the endocrinologist. This fact occurred 4 years after the diagnosis of the visual disturbance, when the patient already presented important short stature secondary to GH deficiency.

Two patients forwarded by Neurology already had two non-endocrine criteria of SOD, however they only had their diagnosis confirmed years after the beginning of the neurological monitoring; one of them by the endocrinologist and other by the geneticist. Of the 4 patients diagnosed by the endocrinologist, 2 also had a great delay in diagnosis due to a lack of knowledge about the syndrome by the specialists. One of the cases, although extensively monitored by a multidisciplinary team, never had been evaluated by an endocrinologist until the age of 13 .

Two patients presented significant hypoglycemic episodes since the neonatal period, both complicated by seizures, one being victim of cardiorespiratory arrest in the postnatal period. These children had multidisciplinary follow up, but the etiology of the hypoglycemia was elucidated and treated very late in life. It is known that the recurrent hypoglycemia may cause irreversible neurological damage. As the situation progressed, associated growth deficit, nystagmus, visual loss and developmental delay were observed and the diagnosis of the hypopituitarism occurred really late at 4.5 and 13 years of age, when the therapeutic measures are less efficient. In one of the cases, the stature deficit can't be corrected with hormone substitution because the patient is already in the final phase of growth. At age 13, the height of the patient is of $-3.9 \mathrm{SD}$, three standard deviation below the family target. Although dynamic tests were not made for the confirmation of the GH deficiency, it probably exists, being suggested by the combination of abnormalities in the hypothalamic-pituitary axis, severe short stature and insignificant plasmatic IGF-1 levels.

The literature highlights that neonatal hypoglycemia is an important alert sign for the suspicion of hypopituitarism, which could be treated early in life to reduce the neurocognitive morbidity. Studies show that there is a significant delay (2 to 6 years) on the diagnosis of SOD in patients with visual and growth disturbances, even in those with history of recurrent hypoglycemia in the neonatal period and early diagnosis of visual abnormalities in the first year of life ${ }^{29}$. Our cases reveal that there has been a delay between the diagnosis of $\mathrm{ONH}$ and the definition as SOD of 2 to 12 years (average of 6 years). Other important characteristic to be remembered on the follow-up of these patients is the evolution of the endocrine deficiencies through time, as occurred with two patients, 
which demands clinical vigilance and periodic reevaluation of the endocrine function ${ }^{7,18,25}$.

In accordance to the literature $\mathrm{e}^{4,5,7,11,19,24,25,30}$, it is observed a great phenotypic variety of the endocrine manifestations on the SOD cases, varying from normal pituitary function - one case - to severe hypopituitarism - in three cases. One of the patients has isolated ADH deficiency, a rare fact according to the literature ${ }^{5,26}$, but with the possibility of developing other deficiencies, since the patient is still young (8 years), needing close follow up.

We noticed a strong association between the hypothalamic-pituitary axis abnormalities on the MRI and endocrine disfunction, as the patient with an empty sella was the most compromised, while the patient with a normal MRI had a preserved pituitary function. All of the patients with abnormal hypothalamic-pituitary axis presented neuroendocrine dysfunctions but we didn't observe any relation between the hormonal deficit and the anomalies found on the neuroimaging, as the image of the sella of the patient with diabetes insipidus is identical to the findings of the patients with combined pituitary hormone deficiency.

Four of our patients presented developmental delay, which can be difficult to evaluate due to the diverse concomitant factors present in the syndrome, as it is unknown for certain for how many years the patients had already presented hypothyroidism before the beginning of the treatment. It is good to remember that hypothyroidism not treated in the first 3 years of life has adverse effects in the development of the brain, maybe contributing to the developmental delay observed in these cases.

Two other cases, even with the important visual deficit, did not have specialized follow up, which could have optimized its development potential. Other factor that may have contributed to the neurological condition of these patients are the cerebral malformations, because both present schizencephaly. Additionally, one of them presents cortical dysplasia, a finding that by itself justifies and predicts the worst neurological prognosis as described by Brodsky and Glasier ${ }^{8}$. Besides, the patient who presents the highest neurological handicap may have also suffered undiagnosed hydroelectrolyte disturbances secondary to the diabetes insipidus, which could have aggravated the cognitive prognosis.

Other interesting finding is that three (60\%) of our patients presented arachnoid cysts, an association already described $^{6}$ and present in $12.5 \%$ of the patients ${ }^{23}$ with $\mathrm{ONH}$. It could be a causative factor or only secondary to a common etiopathogenic process ${ }^{23}$.

We did not observe any prenatal problems that usually are associated to SOD or ONH and only one patient had fetal distress, solved by cesarean surgery. We described, however, two patients, of the male gender, that were SGA without defined etiology. Both present brain malformation that don't directly justify intrauterine growth retardation (IUGR), but could come from a common gestational disturbance that could cause the SOD and the IUGR.

Although none of our patients have a family history of SOD or hypopituitarism, this does not exclude the possibility of a genetic cause for the syndrome. This investigation still has not been done.

Although rare, SOD is an important cause of congenital hypopituitarism and should be considered in all children with $\mathrm{ONH}$ or midline defects, pursuing the early diagnosis and treatment of aggravated endocrine and neurologic functions, with consequent reduction of morbid-mortality.

Ophthalmologists and neurologists should be aware to the identification of any of the features of the syndrome, forwarding these patients early to the pediatric endocrinologist, since the pituitary deficiencies may be present since the neonatal period or can appear throughout life, originating permanent sequelae.

\section{REFERENCES}

1. Reeves DL. Congenital absence of septum pellucidum. Bull Johns Hopkins Hosp 1941;69:61-71

2. de Morsier G. Études sur les dysraphies cranio-encephaliques: III. Agenesie du septum lucidum avec malformation du tractus optique: La dysplasie septo-optique. Schweizer Arch Neurol Psychiatr 1956; 77:267-292.

3. Patel L, McNally RJ, Harrison E, Lloyd IC, Clayton PE Geographical distribution of optic nerve hypoplasia and septo-optic dysplasia in Northwest England. J Pediatr 2006;148:85-88.

4. Dattani MT. Growth hormone deficiency and combined pituitary hormone deficiency: does the genotype matter? Clin Endocrinol (Oxf) 2005;63:121-130.

5. Izenberg N, Rosenblum M, Parks JS. The endocrine spectrum of septo-optic dysplasia. Clin Pediatr 1984;23:632-636.

6. Zeki SM, Hollman AS, Dutton GN. Neuroradiological features of patients with optic nerve hypoplasia. J Pediatr Ophthalmol Strabismus 1992;29:107-111.

7. Kelberman D, Dattani MT. Septo-optic dysplasia: novel insights into the aetiology. Horm Res 2008;69:257-265.

8. Brodsky MC, Glasier CM. Optic nerve hypoplasia: clinical significance of associated central nervous system abnormalities on magnetic resonance imaging. Arch Ophthalmol 1993;111:66-73.

9. Morishima A, Aranoff GS. Syndrome of septo-optic pituitary dysplasia: the clinical spectrum. Brain Dev 1986;8:233-239.

10. Acers TE. Optic nerve hypoplasia: septo-optic-pituitary dysplasia syndrome. Trans Am Opthalmol Soc 1981;79:425-427.

11. Siatkowski RM, Sanchez JC, Andrade R, Alvarez A. The clinical, neuroradiographic, and endocrinologic profile of patients with bilateral optic nerve hypoplasia. Ophthalmology 1997;104:493-496

12. Campbell CL. Septo-optic dysplasia: a literature review. Optometry 2003; 74:417-426

13. Roesmann U, Velasco ME, Small EJ, Hori A. Neuropathology of "septo-optic dysplasia" (de Morsier syndrome) with immunohistochemical studies of the hypothalamus and pituitary gland. J Neuropathol Exp Neurol 1987;64:597-608.

14. Thomas PQ, Dattani MT, Brickman JM, et al. Heterozygous HESX1 mutations associated with isolated congenital pituitary hypoplasia and septo-optic dysplasia. Hum Mol Genet 2001;10:39-45

15. Roberts-Harry J, Green SH, Willshaw HE. Optic nerve hypoplasia: associations and management. Arch Dis Child 1990;65:103-106.

16. McNay DE, Turton JP, Kelberman D, et al. HESX1 mutations are an uncommon cause of septooptic dysplasia and hypopituitarism. J Clin Endocrinol Metab 2007;92:691-697.

17. Garcia ML, Ty EB, Taban M, David Rothner A, Rogers D, Traboulsi El. Systemic and ocular findings in 100 patients with optic nerve hypoplasia. J Child Neurol 2006;21:949-956.

18. Brook CGD, Sanders MD, Hoare RD. Septo-optic dysplasia. BMJ 1972;3:811-813. 
19. Riedl SW, Müllner-Eidenböck A, Prayer D, Bernert G, Frisch H. Auxological, ophthalmological, neurological and MRI findings in 25 Austrian patients with septo-optic dysplasia (SOD): preliminary data. Horm Res 2002;58(Suppl 3):S16-S19.

20. Burke JP, O'Keefe M, Bowell R. Optic nerve hypoplasia, encephalopathy, and neurodevelopmental handicap. Br J Ophthalmol 1991;75:236-239.

21. Costin G, Murphree AL. Hypothalamic-pituitary function in children with optic nerve hypoplasia. Am J Dis Child 1985;139:249-254.

22. Margalith D, Jan JE, McCormick AQ, Tze WJ, Lapointe J. Clinical spectrum of congenital optic nerve hypoplasia. Review of 51 patients. Dev Med Child Neurol 1984;26:311-322

23. Lyons C, Castano G, Jan JE, Sargent M. Optic nerve hypoplasia with intracranial arachnoid cyst. J AAPOS 2004;8:61-66.

24. Cameron FJ, Khadilkar V, Stanhope R. Pituitary dysfunction, morbidity and mortality with congenital midline malformation of the cerebrum. Eur J Pediatr 1999:158:97-102
25. Haddad NG, Eugster EA. Hypopituitarism and neurodevelopmental abnormalities in relation to central nervous system structural defects in children with optic nerve hypoplasia. J Pediatr Endocrinol Metab 2005;18:853-858.

26. Huseman CA, Kelch RP, Hopwood NJ, Zipf WB. Sexual precocity in association with septo-optic dysplasia and hypothalamic hypopituitarism. J Pediatr 1978:92:748-753.

27. Martínez-Sánchez L, Arce A, Caritg-Bosch J, Campistol J, Pavía C, Gean-Molins E. Septo-optic dysplasia. Rev Neurol 2002;35:439-442.

28. Brodsky MC, Conte FA, Taylor D, Hoyt CS, Mrak RE. Sudden death in septooptic dysplasia: report of 5 cases. Arch Ophthalmol 1997;115:66-70.

29. Mutz I, Millner M, Borkenstein M. Optic nerve hypoplasia and growth hormone deficiency: de Morsier's syndrome. Wien Klin Wochenschr 1984;96:432-435.

30. Brickman JM, Clements M, Tyrell R, et al. Molecular effects of novel mutations in Hesx1/HESX1 associated with human pituitary disorders. Development 2001:128:5189-5199. 